EPiC Series in Engineering
Volume 3, 2018, Pages 26-35
HIC 2018. 13th International
Conference on Hydroinformatics

\title{
A Contribution to an Advisory Plan for Integrated Irrigation Water Management at Nebhana Dam System: from Research to Operational Support
}

\author{
M. Allani ${ }^{1,3}$, R. Mezzi ${ }^{1}$, W.Abdallah ${ }^{1,3}$, A. Gharbi ${ }^{1,3}$, A. Zouabi ${ }^{2}$, K. \\ Hedhli $^{2}$, R. Béji ${ }^{2}$, A. Jemli ${ }^{2}$, F. Joumade-Mansouri' ${ }^{2}$, E. Affli ${ }^{2}$, M.E. Hamza ${ }^{1}$, \\ H.W. Müller ${ }^{3}$ A. Sahli ${ }^{1}$ \\ 1 Université de Carthage, Institut National Agronomique de Tunisie (INAT), Tunis, Tunisia \\ 2 Commissariat Régional au Développement Agricole de Kairouan (CRDA), Tunisia \\ 3 Bundesanstalt für Geowissenschaften und Rohstoffe (BGR), Hannover, Germany \\ mohamed.allani@gmail.com; sahli_inat_tn@yahoo.fr
}

\begin{abstract}
In the agriculture sector, combining physically based soil water balance and simulation models with GIS tools is of a considerable interest to manage the available water amount. Indeed, this combination can enhance water supply management, optimize agricultural catchments management and study impact of management intervention from small scale (plot) to a larger one, such as irrigated district and/or region.

This work presents the case of Nebhana Dam System in the region of Kairoun (central Tunisia). The main objectives were to: (1) create a specific GIS database for the six irrigated districts of the area Ain Boumorra 1, 2 \& 3, Fadhloun, Dar Jameya and Sisseb 1 based on the characteristics of cultivated crops, soils types and used irrigation systems; (2) assess spatial and temporal variation of soil water budget terms from plot and farm levels to irrigated district and regional scales; (3) map results for different time steps.

The achievement of these objectives was made possible using the WEAP-MABIA Model. Thus, daily Penman-Monteith reference evapotranspiration (ETo), effective precipitation $(\mathrm{PE})$, crop water requirement $(\mathrm{CWR})$ and irrigation water requirement (IWR) were estimated for the six irrigated districts and their related farms and plot using spatially distributed parameters on climate, crop, soil characteristics, irrigation system and basic irrigation management practice during the cropping season 2014/2015.
\end{abstract}




\section{Introduction}

The rational management of water resources in agriculture is becoming more and more a crucial issue for the environmental and economic sustainability of the primary sector especially in the regions where water is scarce and should be saved for other uses. Efficient management of land and water resources in irrigated agriculture requires comprehensive knowledge on many variables including climate, soil, land use, crops, water availability, water distribution networks, management practices, etc. Most of these data are spatially distributed and their integration and use in irrigation planning and management has promoted the widespread utilization of Geographic Information Systems (GIS) and other modern information technologies (Todorovik et Steduto 2003, D'Urso, De Michele et Falanga Bolognesi 2013).

The purpose of this work is to present the development, operational functionalities and spatial modeling applications of a GIS-based irrigation water management system, to provide farmers, Water Users Associations and Local Authorities in Kairouan region with spatial and temporal information on Crop Water Requirement (CWR) and Irrigation Water Requirement (IWR). This work was implemented within the framework of the CREM-BGR project, funded by the German Cooperation and aimed to strengthen water management in Maghreb countries.

\section{Description of the Study Area}

The study area "Nebahana System" corresponds to a water management area with the Nebhana Dam as the main water resource supply. It is located in the Kairouan Governorate, centre of Tunisia (Figure 1). Regarding the water management procedures from the Dam, the Société d'Exploitation du Canal et Adductions des Eaux du Nord (SECADENORD) is in charge of providing water for agricultural and domestic purposes for 4 governorates namely, Kairouan, Sousse, Monastir and Mahdia, through a pipeline. The study focus on the six public irrigated districts in the Kairouan governorate because of the higher irrigation demand when compared to the other areas. In fact, for the period Januray 2014 to December 2015, the average monthly water consumption in Kairouan was $371 \mathrm{~m}^{3} /$ ha but did not exceed $225 \mathrm{~m}^{3} /$ ha for the three remaining governorate. Water management, distribution and maintenance of the primary network is ensured by the Commissariat Regional au Developpement Agricole of Kairouan (CRDA-Kairouan).

At the level of each irrigated district, a Water User's Associations ensure the distribution of the water between farmers, the billing and the maintenance of the network within the irrigated district. The six irrigated district in Kairouan are Ain Boumorra 1, 2 \& 3, Fadhloun, Sisseb 1 and Dar Jameya. They occupy a total area of 2068 ha. Land use main crops are Apricot, Citrus, Olive, Green peas, Pepper, Barley and Wheat.

The study area belongs to the upper semi-arid bioclimatic stage, with a cool wet season from November to March and a dry hot season from May to September. Average (1981-2015) annual rainfall are $313 \mathrm{~mm}$ and average (1981-2015) Reference Evapotranspiration ETo are $1326 \mathrm{~mm}$. 

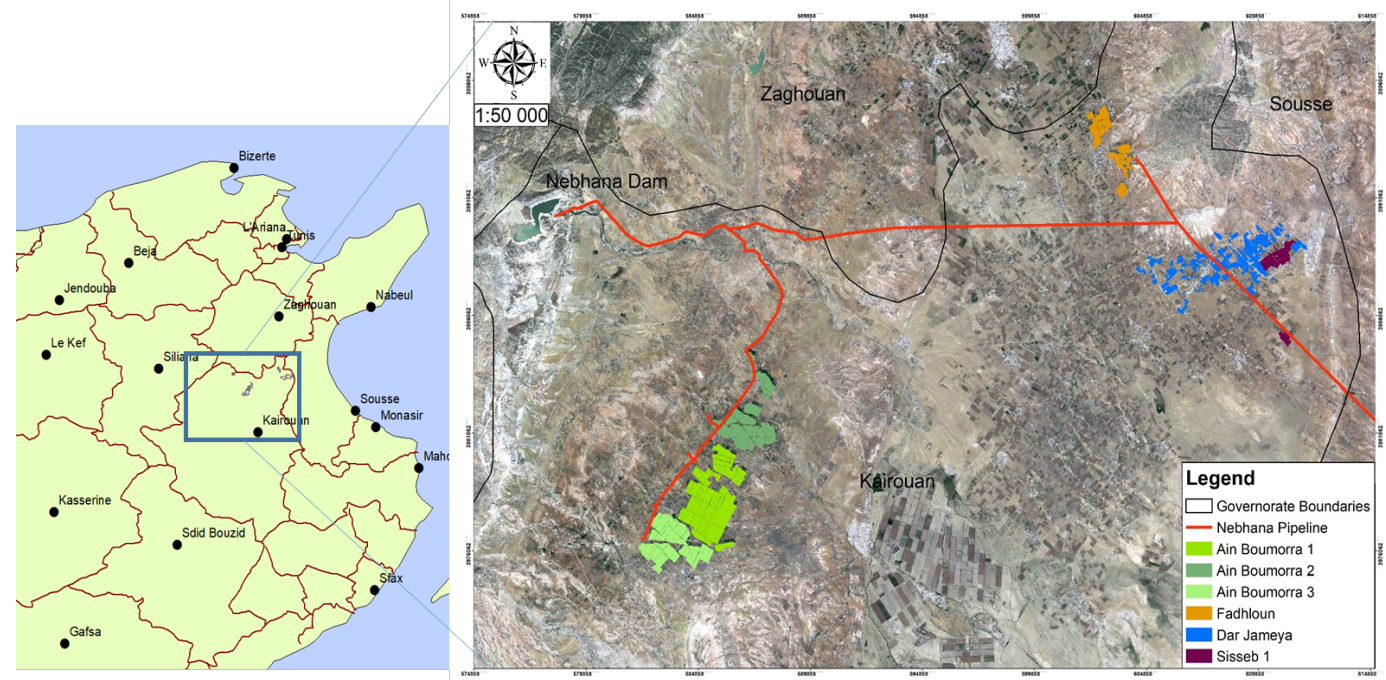

Figure 1: Location of the study area "Nebhana System" in Kairoaun

\section{Methodology}

\subsection{Development of a GIS based Data Base}

The use of GIS to design an integrated irrigation water management service requires a procedure for adequate depiction of the system. The database represents a combination of information coming from different sources and formats. The GIS database has to be composed of different thematic layers and then according to the specific needs, the layers are integrated and used for the creation of thematic maps.

The collected data include, irrigated districts limits, farms and plots limits, water network transfer, physical soil characteristics, land use and irrigation systems.

\subsubsection{Scanning and Georeferencing of existing maps and hydraulic infrastructures}

Existing maps of water network and irrigated districts limits were scanned and imported in QGISC. Geo-referencing was done using ground control points.

All coordinates are reported in $\mathrm{X}$ et $\mathrm{Y}$ coordinates as per the following projection parameters:

- Coordinate System: WGS 84

- Projection: Universal Transverse Mercator Zone $32 \mathrm{~N}$

Based on the georeferenced maps of the irrigation networks, a database of the different networks was created for each irrigated district, contained information about pipe length, Diameter and type. Concerning the hydraulics infrastructures, their localization was done using a GPS and data concerning their characteristics were collected and implemented in the database. For the hydrants, name of user, ID and $\mathrm{X} \& \mathrm{Y}$ coordinates were added. 


\subsubsection{Creation of the soil physical characteristics maps}

Particle size distribution data (\% Sand, \% Silt \% Clay) of 53 soil samples of the area were collected and an interpolation map was created using the Inverse Distance Weighting (IDW) (Gozdowski, et al. 2015) interpolation method in QGIS ${ }^{\mathcal{C}}$.

\subsubsection{Delineation of farms and plots}

Based on field survey and the collaboration of the Water Users Associations of each irrigated district, the delimitation of each farm and each plot was done.

\subsubsection{Plot characteristics: land use and irrigation systems}

For each delimitated plot, data regarding the land use for the growing season 2014/2015 and the irrigation system used was collected by field survey during winter and summer periods.

\subsection{Decision Support System Software}

The supply and demand of irrigated sector assessed at the different spatial and temporal scales require linking land cover information from land survey and GIS, with data from field monitoring and modelling. We used the Water Evaluation and Planning "WEAP" (Seiber et Purkey 2012) and its MABIA module (Jabloun et Sahli, WEAP-MABIA Tutorial 2012) to calculate spatially explicit water balances, to model and map the water provisioning across the landscape, and to elucidate general patterns and changes in water demand caused by changes in climate and land cover at plot, farm, irrigation district and regional levels.

\subsubsection{Water Evaluation and Planning Tool (WEAP)}

The Water Evaluation and Planning (WEAP) is one of the main Decision Support System (DSS) used for integrated water resource management and planning. It offers an-easy-to use framework for water planning and scenario assessment. WEAP simulate the water balance on a monthly basis of the water demand, supply, flow, storage and allow assessing water resource management policies between different sectors (Agriculture, Tourism, Industry...). It can be used at the level of a catchment as well as at a more complex level like Region and Country (Seiber et Purkey 2012)

Recently, WEAP has been widely used for various management problems including modelling water supply and demand at regional level (Hunter, et al. 2015), assessment of climate change impact of water resource (Barnabas Amisigo, McCluskey et Swanson 2015) and water irrigation management (Al-Omari, et al. 2015, Allani, et al. 2012).

\subsubsection{Water Balance Model: MABIA Sub-Model in WEAP}

Within WEAP, different agricultural catchment calculation methods can be used. In this study, we use the MABIA crop module (Jabloun et Sahli, WEAP-MABIA Tutorial 2012) that simulates irrigation catchment performance. The WEAP-MABIA method permits to simulates daily evaporation and transpiration, irrigation requirements, crop growth and yields. The MABIA Method uses the 'dual' crop coefficient $\mathrm{Kc}$ method $(\mathrm{Kc}=\mathrm{Ke}+\mathrm{Ks} \mathrm{Kcb})$, as described in (Allen, et al. 1998), whereby the Kc value is divided into a 'basal' crop coefficient, $\mathrm{Kcb}$, and a separate component, Ke, representing evaporation from the soil surface. The basal crop coefficient represents actual ET conditions when the soil surface is dry but sufficient root zone moisture is present to support full transpiration. 


\subsubsection{Conceptual representation and Model Input}

The geographical focus of the Nebhana Dam system WEAP model is the dam basin and includes representations of the main water management features within the watershed. This includes all of the major tributaries, the main reservoirs (Nebhana Dam), the groundwater aquifers (Sisseb and Ain Boumorra), the major irrigation pipes and the agricultural demands that are associated with this supply source.

The WEAP schematic shows, how the main features of the Nebhana Dam System have been disaggregated and represented in WEAP as so-called supply and demand nodes, transmission links between these nodes and water allocation rules (demand and supply priorities). Figure 1 illustrates the example of the conceptual schema, i.e. spatial layout, elaborated for Ain Boumorra irrigated districts 1, $2 \& 3$ where the "farms" map was added as background. Each agricultural catchment node represents the farm in the respective part of the irrigated district. Plots and plot-specific data were implemented individually in WEAP in each node as detailed as available. Hence, the water demand analysis in WEAP will be done by the disaggregated end-use based approach of calculating crop water requirements (CWR) and irrigation water requirements (WIR) at each demand node.

Simulation of the water balance by WEAP-MABIA requires input data for each plot related to the Land Use with Area and Crop, the Climate and the Irrigation. Plot area and cover were based on the "Land Use" map. The Tunisian Meteorological Agency (INM) gave daily Climate data (minimum and maximum temperature, minimum and maximum air relative humidity, sunshine duration, wind speed and rainfall). Those data were used for the calculation of the reference evapotranspiration (ETo). The soil water capacity (SWAC) was obtained after processing soil particle size data collected from the Soil Department with MABIA-SWAC sub-module according to pedotransfer functions developed by (Vereecken, et al. 1989, Wösten, et al. 1999, Jabloun et Sahli 2006). Crop - specific parameters given in MABIA-Crop Library were derived from the FAO Irrigation and Drainage Paper No.56 (Allen, et al. 1998).

Special attention was paid to building crop input data, particularly planting date, crop growth stage durations, maximum height and rooting depth, as those parameters have been described to play a fundamental role in the model outcomes. Those data as well as irrigation systems were collected during field surveys. Crop Water Requirement (CWR) and Irrigation Water Requirement (IWR) were estimated by considering an explicit irrigation scheduling with a timing criterion "When $90 \%$ of the Readily Available Water (RAW) in the rooting depth were consumed" and a depth criterion "Refilling Soil Water Capacity".

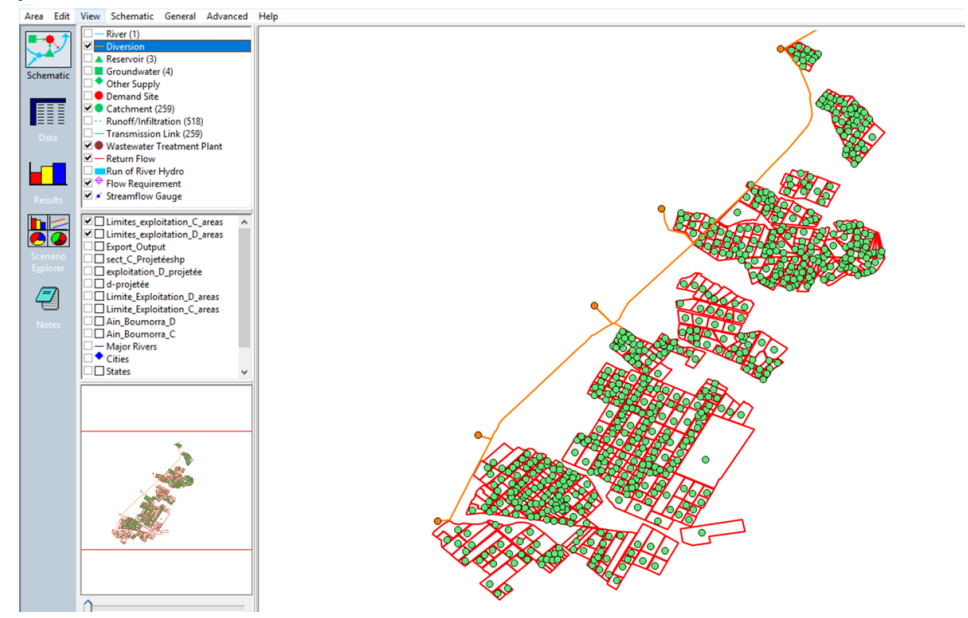

Figure 2: Conceptual schema of Aïn Boumorra 1,2 \& 3 irrigated districts elaborated in WEAP 


\section{Results}

\subsection{Developed GIS for Irrigation Water Management}

The developed GIS was done for the six irrigated districts. The main characteristics are summarized in table 1.

As an example, the irrigated districts of Ain Boumorra $1,2 \& 3$ are presented in figure 2. Figure 2(a) represent the irrigation network and 2(b) the plots limits and their crop cover during the growing season 2014/2015. The irrigation networks of the irrigated districts of Ain Boumorra 1, 2 \& 3 extend to $96.2 \mathrm{~km}$ serving 442 hydrants.

\begin{tabular}{lccccc}
\hline Irrigated District & $\begin{array}{c}\text { Total Area } \\
\text { (ha) }\end{array}$ & Number of Farms & Plots & Network (km) & Number of Hydrants \\
\hline Ain Boumorra 1 & 624.6 & 258 & 455 & 36.95 & 28 \\
Ain Boumorra 2 & 361.5 & 256 & 404 & 28.34 & 228 \\
Ain Boumorra 3 & 376.2 & 162 & 260 & 30.91 & 186 \\
Fadhloun & 184 & 279 & 403 & 13.03 & 72 \\
Dar Jameya & 449.3 & 191 & 485 & 18.52 & 43 \\
Sisseb 1 & 117.6 & 59 & 125 & 6.5 & 37 \\
\hline
\end{tabular}

Table 1: Main characteristics of the six irrigated districts in Kairouan

Regarding land use, during the growing season 2014/2015, the mains cultivated crop in the irrigated districts of Ain Boumorra 1 was Apricot, Olive tree and Green Peas with respectively 41.4\%, 18.8 and $12.3 \%$ of the total area. For the irrigated district of Ain Boumorra 2 the main crop are Citrus, Olive trees and Apricot with $27.1 \%, 26.5 \%$ and $23.5 \%$ of the total area respectively. For the irrigated district of Ain Boumorra 3, main cultivated crops were Apricot, Olive trees and Green Peas representing 40.9\%, $27.3 \%$ and $18.7 \%$ respectively.

Integration of data and consequent customization of GIS environment, presented in this work, are developed for the purpose of satisfying requirements of the final users of GIS database, which are, in this case, the implicated regional (CRDA - Kairouan) and local authorities (CTV - Cellule Territoriale de Vulgarisation - public extension service) as well as the Water Users Associations. The Project Team held a meeting to explain the developed GIS model and provided training to support the staff from the relevant agencies on GIS tools use. A Restitution Workshop was also organized to present and review the developed GIS to all the beneficiaries' personal and interested stakeholders. A Technical Report of the developed GIS, all digital data and maps were prepared and distributed to all implicated administrations as part of the Validation Workshop (Allani, Mezzi, et al. 2016). In addition, on request of the regional stakeholders, complementary work on the GIS model was carried out as well as ground truthing and on-the-job training to relevant administration officers in charge of GIS in Kairouan. The trained staff should be able in the future to improve/adapt/update the developed GIS.

\subsection{Information on Crop Water Requirements over temporal dimension}

Potential crop evapotranspiration (ETc) is the crop water requirement, or the optimal amount of water that the crop needs to face the atmospheric water demand, was calculated with WEAP-MABIA. It takes into account the actual crop conditions for each day in terms of crop growth stage and climate conditions, monitored by means of daily reference evapotranspiration (ETo) data. 

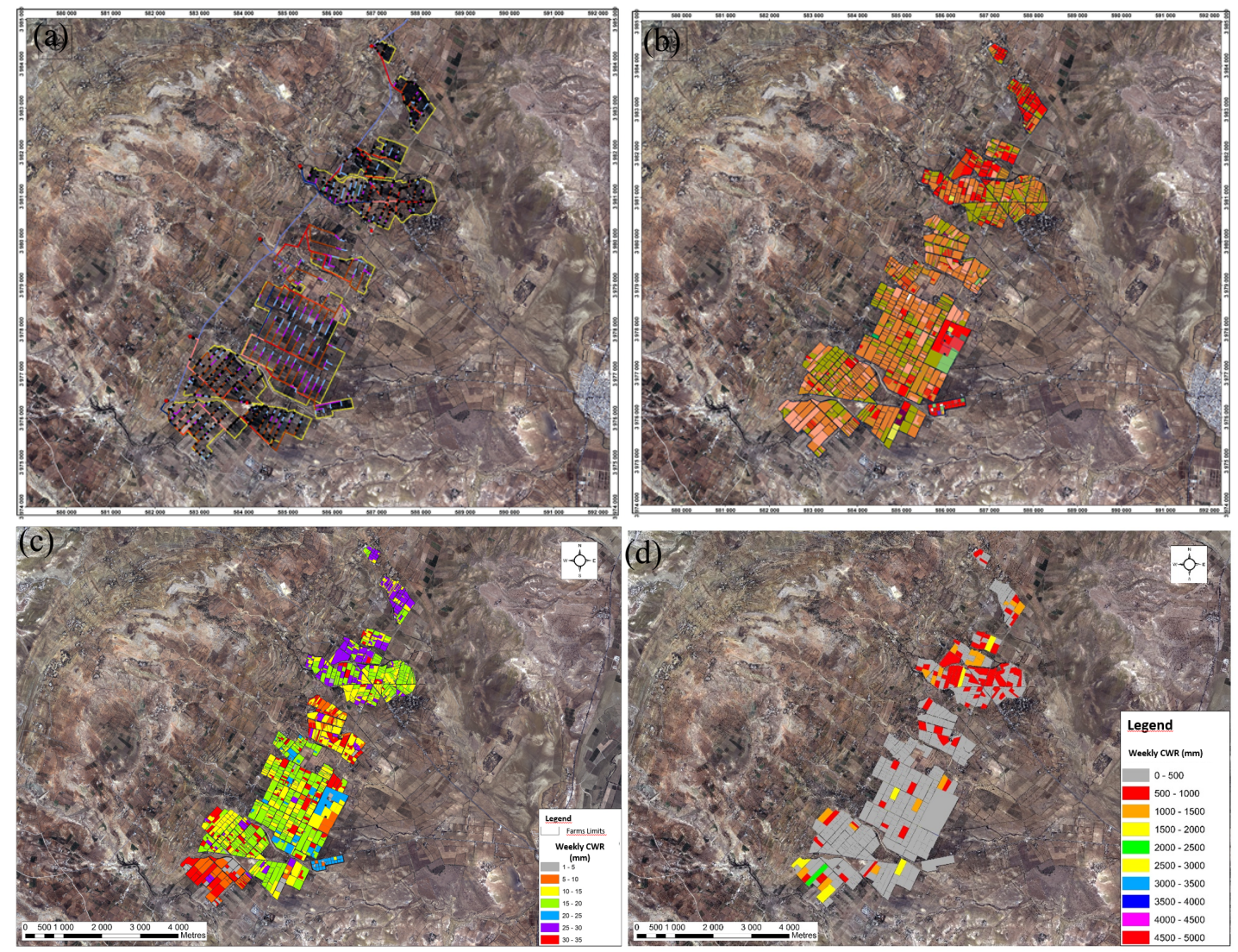

Figure 3: Examples of GIS based WEAP-MABIA Model: (a) Network distribution; (b) Land use; (c) CWR and (d) IWR of the irrigated districts Ain Boumorra 1, 2 \& 3

The daily crop water needs values obtained here are consistent with those of other studies under the same climatic conditions. As an example, ETc value of the olive trees during the growing season 2014/2015 were $809 \mathrm{~mm}$ year ${ }^{-1}$ similar to the value found by (Ezzahar, et al. 2007) in morocco (920 $\mathrm{mm}$ year $\left.{ }^{-1}\right)$ and (Orgaz, et al. 2005) (835 mm year $\left.{ }^{-1}\right)$ in Spain. Concerning the citrus the obtained ETc was $1367 \mathrm{~mm}_{\text {year }}{ }^{-1}$. The estimated value compares well with different studies ranging from $1257 \mathrm{~mm}$ year ${ }^{-1}$ in Sao Paulo, Brazil (Alves, et al. 2006) to $1390 \mathrm{~mm}$ year ${ }^{-1}$ in California, USA (Snyder et O'Connell 2007). The green peas crop water requirement was also correctly estimated with an ETc of $412 \mathrm{~mm}$ year ${ }^{-1}$ when (Saha 2011) found $489 \mathrm{~mm}$ year-1 in Neh Region, India.

By means of the developed DSS, we derived daily potential crop evapotranspiration maps for the whole agricultural area which can be aggregated for different time steps. Figure 2(c) shows, as an example, maps of Crop Water Requirements (CWR) computed on weekly ( $7^{\text {th }}$ to $13^{\text {th }}$ April 2015) basis.

\subsection{Information on Irrigation Water Requirements over the temporal dimension}

Irrigation water requirement (IWR) is the total quantity of water applied to the land surface in supplement to the water supplied through rainfall and soil water profile to meet the water needs of crops for optimum growth, i.e. the crop water requirements (CWR). It takes into account the actual crop 
conditions for each day in terms of soil water depletion, crop water requirements and crop sensitivity to water stress, rooting depth, soil water capacity and climate conditions (reference evapotranspiration and rainfall).

From the daily water balance, we derived by means of the developed DSS daily irrigation water requirements maps with values expressed in $\mathrm{mm}^{-1 a y^{-1}}$ or in $\mathrm{m}^{-3}$ day $^{-1}$ by considering the parcel area $\left(1 \mathrm{~mm}\right.$ day ${ }^{-1}$ corresponds to $10 \mathrm{~m}^{-3} \mathrm{ha}^{-1}$ day $\left.^{-1}\right)$. Maps obtained for the different crops were summarized to derive daily maps of irrigation water requirements for the whole agricultural area which can be aggregated for different time steps. Figure 2-d shows, as an example, maps of Irrigation Water Requirements (IWR) at farm level for the week 7 - 13 April 2015.

The suggested methods for daily IWR estimation during the cropping season give a very good indication of its spatial distribution and could be used directly in irrigation alert by the Water Users Association and in irrigation water management by the local and regional Authorities. The reason behind this is the wide fluctuation of CWR and IWR from day to day, depending on meteorological conditions, availability of water, land use and plant growth. The figure 4 represent the aggregated monthly IWR and the Actual Water Consumption AWC for the six irrigated districts during the Growing season 2014/2015. As the figure shows, annual IWR per irrigated district varied from 0.3 for the irrigated district of Sisseb 1 to $3.9 \mathrm{Mm}^{3}$ for the irrigated district of Ain Boumorra 1. Where annual AWC varied from 0.41 for the irrigated district of Sisseb 1 to $2.5 \mathrm{Mm}^{3}$ for the irrigated district of Ain Boumorra 1. At monthly steps, the figure shows two distinctive periods. During the first period (September 2014 to April 2015) AWC was higher than the IWR where the differences varied from $0.07 \mathrm{Mm}^{3}$ during September to $0.52 \mathrm{Mm}^{3}$ during February. During the second period (May to August 2015), despite the increase in AWC and IWR, AWC was lower than the IWR varying from $0.46 \mathrm{Mm}^{3}$ during July to $1.07 \mathrm{Mm}^{3}$ during August.

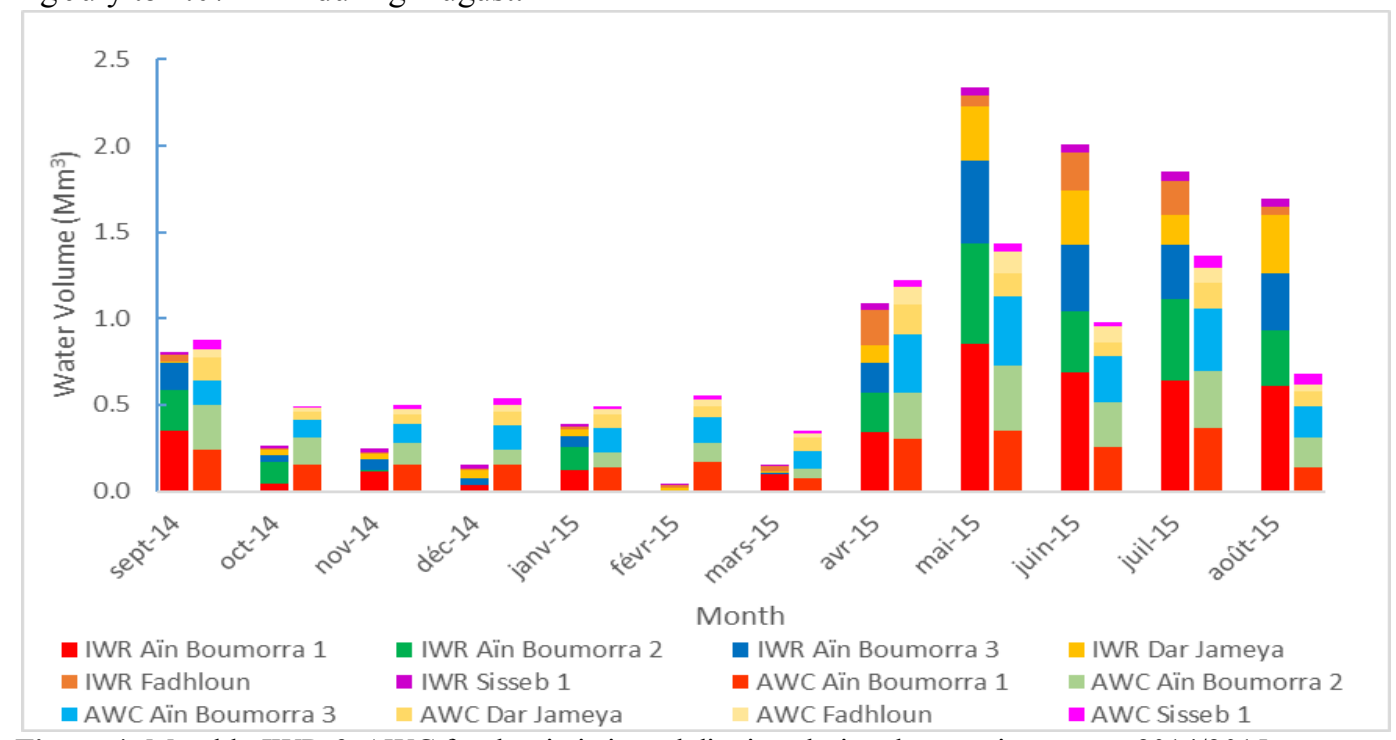

Figure 4: Monthly IWR \& AWC for the six irrigated districts during the growing season 2014/2015

\section{Conclusion}

Irrigation water management is a complex task since it depends upon various factors such as land use, crop growth stage and parameters, climate and soil type data. Efficiency depends upon the reliability of these data. For this, the presented work covers two topics relevant to the improvement of 
irrigation management in Nebhana Dam System: The development of a local GIS irrigation database and the estimation of crop water requirements and irrigation water requirements, by mean of a dedicated WEAP-MABIA DSS. Combining these two tools has been embedded in an integrated methodology, which will be operational since it is implemented according to request of local water managers and the regional stakeholders. Besides, this latter accepts input from multiple data sources and offers options for updating data and including alternative methods. The delivered information is maps of the Nebhana Dam System with its six irrigated districts and their related farms and plots; representing the current land use, the crop water requirement (CWR) and the irrigation water requirement (IWR) at daily, weekly and monthly steps. Also and thanks to WEAP tool functionalities, these results can be displayed on Google Earth and shared between all water irrigation managers (results not shown) to improve the irrigation scheduling, and accordingly, to make a better decision about which field (or crops) to irrigate, when and how much.

\section{References}

Allani, M., M. Jabloun, A. Sahli, V. Hennings, J. Massmann, et H. W. Müller. 2012. «Enhancing on farm and regional irrigation management using MABIA-Region tool.» 4th International Symposium on Plant Growth Modeling, Simulation, Visualization and Applications (PMA12). Shanghai: IEEE . 18-21.

Allani, M., R. Mezzi, W. Abdallah, R. Jlassi, N. Boukhalfi, A. Romdhane, F. Stoffner, et al. 2016. Support Technique : Cartes thématiques de l'usage agricole de l'eau dans la zone NebhanaSbikha. CRDA Kairouan - Projet CREM-Volet BGR.

Allen, R. G., L. S. Pereira, D. Raes, et M. Smith. 1998. Crop evapotranspiration - guidelines for computing crop water requirements. Édité par Food and Agriculture Organization. Vol. 56. Rome: FAO Irrigation and Drainage Paper.

Al-Omari, A. S., E. K. Al- Karablieh, Z. M. Al-Houri, A. Z. Salman, et R. A. Al-Weshah. 2015. «Irrigation Water Management in the Jordan Valley Under Water Scarcity.» Fresenius Environmental Bulletin 24: 1176-1188.

Alves, J., M. V. Folegatti, L. R. Parsons, W. Bandaranayake, C. R. da Silva, T. J. A. da Silva, et L. F. S. M. Campeche. 2006. «Determination of the crop coefficient for grafted 'Tahiti' lime trees and soil evaporation coefficient of Rhodic Kandiudalf clay soil in Sao Paulo, Brazil.» Irrigation Science 25 (4): 419-428.

Barnabas Amisigo, A., A. McCluskey, et R. Swanson. 2015. «Modeling Impact of Climate Change on Water Resources and Agriculture Demand in the Volta Basin and other Basin Systems in Ghana.» Sustainability 7: 6957-6975.

D'Urso, G, C De Michele, et S Falanga Bolognesi. 2013. «IRRISAT, the Italian On-line Satellite Irrigation Advisory Service.» Sustainable Agriculture through ICT Innovation, EFITAWCCA-CIGR Conference. Turin, Italy.

Ezzahar, J., A. Chehbouni, J. C. B. Hoedjes, S. Er-Raki, A. Chehbouni, G. Boulet, J. M. Bonnefond, et H. A. R. De Bruin. 2007. «The use of the scintillation technique for monitoring seasonal water consumption of olive orchards in a semi-arid region.» Agricultural Water Management 89 (3): 173-184.

Gozdowski, D., M. Stępień, S. Samborski, et E. S. Dobe. 2015. «Prediction accuracy of selected spatial interpolation methods for soil texture at farm field scale.» Journal of soil science and plant nutrition 639-650.

Hunter, C., J. Gironás, D. Bolster, et C. A. Karavitis. 2015. «A Dynamic, Multivariate Sustainability Measure for Robust Analysis of Water Management under Climate and Demand Uncertainty in an Arid Environment.» Water 7: 5928-5958. 
Jabloun, M., et A. Sahli. 2006. «Development and comparative analysis of pedotransfer functions for predicting characteristic soil water content for Tunisian soil.» 7th Tunisia-Japan Symposium on Society, Science and Technology. Tunis. 170-178.

Jabloun, M., et A. Sahli. 2012. WEAP-MABIA Tutorial. Bundesanstalt für Geowissenschaften und Rohstoffe (BGR) [Federal Institute for Geosciences and Natural Resources]). Accès le June 12, 2016. www.bgr.bund.de/EN/Themen/Wasser/Produkte/_functions/Produkte_Software_en.

Orgaz, F., L. Testi, F. J. Villalobo, et E. Fereres. 2005. «Water requirements of olive orchards-II: determination of crop coefficients for irrigation scheduling.» rrigation Science 24 (2): 77-84.

Saha, R. 2011. «Prediction of water requirement of garden pea (Pisum sativum) under hilly agroecosystem of Meghalaya.» Indian Journal of Agricultural Sciences 81 (7): 633-636.

Seiber, J., et D. Purkey. 2012. SEI-WEAP-brochure. Accès le June 12, 2016.

Snyder, R. L., et N. V. O’Connell. 2007. «Crop coefficients for microsprinkler-irrigated, cleancultivated, mature citrus in an arid climate.» Journal of irrigation and drainage engineering 133 (1): 43-52.

Todorovik, M, et P Steduto. 2003. «A GIS for irrigation management.» Physics and Chemistry of the Earth 163-174.

Vereecken, H., J. Maes, J. Feyen, et P. Darius. 1989. «Estimating the soil moisture retention characteristic from texture, bulk density, and carbon content.» Soil Science 148: 389-403.

Wösten, J. M. H., A. Lilly, A. Nemes, et C. Le Bas. 1999. «Development and use of a database of hydraulic properties of European soils.» Geoderma 90: 185-196. 